\title{
Lost Hope in Hemingway`s A Farewell to Arms: Existentialism Study
}

\author{
Mahnaz Soqandi ${ }^{1}$, Shiva Zaheri Birgani ${ }^{2}$ \\ ${ }^{1}$ English Language and literature Department, Faculty of Humanities, Semnan University, Semnan, Iran \\ 2Islamic Azad University, Masjed Soleyman, Khuzestan Province, Iran \\ Email: shvzaheri@gmail.com
}

\begin{abstract}
This research paper attempts to explore the novel, A Farewell to Arms through the lens of Existential approach and it explores the role played by Existentialism in the novel. Hemingway is one of the greatest American writers in the twentieth century. A Farewell to Arms, his most famous anti-war novel. An American volunteer joining Italian army falls in love with a British nurse but their love is destroyed mercilessly by the war. Hemingway expresses his outlooks on the world, on life and on individual in this novel. The world under Hemingway's pen is a chaotic and irrational world. People living in this world discard traditional values and faith, living a nihilistic and miserable life. Although the world is absurd and life is nihilistic, the protagonist has fighting spirit. He actively participates in life and pursues the meaning of life. He fights courageously against the danger and death in adversity to realize his existential values. These views are in accordance with existentialist philosophy rising in the twentieth century. Existentialism mainly explores human existence, the absurdity of the world and the meaninglessness and purposelessness of life. Meanwhile it greatly emphasizes man's freedom of choice and action. Living in a chaotic and absurd world, man can never get rid of the sense of nihility. Man has to face it bravely. There is existentialist tendency in A Farewell to Arms, and Hemingway is indeed a writer with existentialist thought.

Keywords: existentialism; subjectivity; freedom to choose; hope; identity
\end{abstract}

\section{Introduction}

Existentialism is the twentieth century philosophy that revolves around the analysis of existence and of the way humans find themselves existing in the world. The notion of Existentialism is that humans exist first and then each individual makes his own essence or nature. In simple words, "Existentialism is concerned about finding self and the meaning of life through free will, choice and personal freedom." It is the belief that people quest for finding who and what they are throughout their life as they make choices based on their beliefs, outlooks and experiences. Hence, personal choices become unique by ignoring objective model of reality. Existentialists believe that each individual should be free to choose what he wants for without the help of laws, rules, and traditions, and should be responsible for his actions. As Jean Paul Sartre points out the existential notion in the mentioned quote: "Man is nothing else but what he purposes, he exists only in so far as he realizes himself, he is therefore nothing else but the sum of his actions, nothing else but what his life is." (qtd. in Sartre 18).

Existentialism as a philosophical movement includes a set of underlying themes and tenets such as freedom, the sense of anxiety, the loss of religious beliefs, meaninglessness and nothingness, self-made meaning, dread, consciousness of death, awareness of existence, absurd, and alienation etc. Some of the Existential themes found in the selected novel are analyzed with reference to the chosen novel of Hemingway in the present study. "There are realities in the external world. These realities are not more than one unity and one thing. This is the human mind that divides the external reality into two points of essence and existence 
(being). Because of this, it becomes necessary that the external reality also be both unique and not unique" (qtd.in Basirizadeh 15).

Existentialism as a philosophical movement has its roots in France, Denmark, Italy and Germany in the early development. "Materialistic behavior as motivated goal pursuit intended to construct and maintain self-identity, and defines materialism as the extent to which people engage in identity maintenance and construction through symbolic consumption"(qtd. in Eskandari 313).

The reaction against Rationalism, European industrial revolution, economic and physical devastation caused by the World War II, and the beginning of the Cold War are the main factors for the rise of the philosophical trend. By the end of the World War II, Existentialism became the most celebrated trend in philosophy and literature as well. In this context, the sole objective of the current study is to make the concept of Existentialism clear. After all, the major objective of the study is to make an exhaustive note on Existentialism depicted in the selected novel (A Farewell to Arms) of American novelist, Hemingway.

\section{Research Methods}

Existentialism attempts to liberate humans from the entangling, paralyzing (as James Joyce refers to) immediate life by focusing on the famous statement of Rene Descartes, "I think; therefore, I am". This humanistic school of thought is to direct humanity toward wellgrounded relationships with others and with themselves. Descartes uses "I" more than any other pronouns just for concentrating on individual. Thomas W. Busch (1990) in his book under the title of 'The Power of Consciousness and the Force of Circumstances in Sartre's Philosophy' refers to Descartes' notion of "autonomous thinking" - I think therefore I am - and its relation to Sartre's existentialism and quotes:

'Descartes realized perfectly that the concept of freedom involved necessarily an absolute autonomy, that a free act was an absolutely new production, the germ of which could not be contained in an earlier state of the world and that consequently freedom and creation were one and the same. The freedom of God, though similar to that of a man, loses the negative aspect that it had in its human envelope; it is pure productivity'. (1990:1).

Of course, Busch focuses on the fact that it is misleading to overestimate Descartes' influence on the development of Sartre's existentialism. World War II had negative effects on Europe's perception of values. Everything was destroyed in war. So many innocent people killed for nothing; henceforth, the stability of the values -especially those values dictated to Christianity- was threatened. The destruction of Europe's social, physical and economical condition led to the obliteration of most spiritual values. As the result, romantic and optimistic portrayals of the world were rejected. The previous state of believes gave its place to a pessimistic and negative one.

'The current movement, however, emerged in France after the horrors of World War II, as a rebellion against essential beliefs and values both of traditional culture and traditional literature. This earlier tradition had included the assumptions that human beings are fairly rational creatures who live in an at least partially-intelligible universe, that they are part of an ordered social structure, and that they may be capable of heroism and dignity even in defeat.' (Abrams, 1969:1) 
In this case, the existentialism became a popular philosophy in the mid-twentieth century. Existentialism tries to see the man as an isolated existent who is "cast into an alien universe, to conceive the universe as possessing no inherent truth, value, or meaning, and to present human life, as it moves from nothingness whence it came toward the nothingness" (Abrams, 1969:1). Thus, existentialism contains a sort of absurdity mixed with a feeling of estrangement. So as many other terms, existentialism is a type of historical movement, mostly devoted to what Jean-Paul Sartre had done as a man of letter. Regarding the difficulty of studying Sartre's philosophy, it is enough to refer to the very first pages of Ronald E. Santoni's 'Bad Faith, Good Faith, and Authenticity in Sartre's Early Philosophy' (1995). He states that:

'The philosophy of Jean-Paul Sartre is one to which too many philosophers, academics, and laypersons allude, but too few read-at least seriously. I believe that if one attempts to penetrate even part of Sartre's vast and complex philosophical system, one is confronted not only with some important insights into our human condition but also with existentially disturbing challenges and gnawing difficulties'. (1995:xv).

It is mainly through the work of Jean-Paul Sartre that existentialism has come to the attention of a wide international audience. His theories were first published in late 1930s and early 1940s, and they were and are still widely read. One of his famous essays which best represents his existential ideas is 'Existentialism is Humanism' written in 1945. It was to address a small public during World War II in Nazi occupied France. Sartre introduced a great number of philosophical concepts in Existentialism. His view toward these concepts addresses his view of life and man.

Originated by Jean-Paul Sartre (1945) in his 'Existentialism is Humanism', the phrase "existence precedes essence" has come to be a sort of defining formulation of the existentialism. By this quotation, Sartre insists that the "essence" or "nature" of a thing is no more fundamental than its "existence". Sartre basically applies this principle to humanity. Traditionally, it was assumed that human's essence precedes existence. Because in Christianity people believed to be created by God. God knew what was to be made before humans ever existed. An existentialist, such as Sartre, goes a step further and rejects this idea (essence precedes existence).

Sartre (1945) in his 'Existentialism is Humanism' argues that there is no given human nature common to everyone, because there is no God to give it in the first place. Human beings exist, and it is just after their existence that some "essence", that can be called "human", may develop. Sartre believes that the nature of every person depends on that person per se. There is a freedom in selecting between this and that; the sort of selection which brings responsibility defines the nature or essence of man.

Thus, no longer some excuses such as "it was in my nature" can be acceptable; since, human beings create their own nature themselves, and also, no longer can they blame anyone, or even praise anyone, but themselves. Sartre continues that there may not be a universal human nature, but there is certainly a common human condition: because we all are living in a society and having common condition, we may all face with the same sort of decisions. Locating in the state of decision, man is not just choosing for himself, rather for all human beings. So, Sartre states that we are not only responsible for ourselves but also bear some responsibility for others. Knowing that by choosing for yourself, you are choosing for human beings, and also the responsibility of the choice is on your own, humanism is going to be created by one's choice. 
Man in existentialism is known as a self-conscious subject, dealing with his or her own existence. Believed to be thrown in the irrational world, man tries to deal with the meaningless and purposeless world around and asks a question of why? Man is thus faced with the nothingness and meaninglessness of his/her existence, the anxiety and despair that result from this realization -that at last lead him/her to accept this reality-, the responsibility of providing an answer to the question by himself/herself, all lead the man to be regarded as a free existence having the freedom to choose.

\section{Discussion}

\subsection{Existentialism in Farewell to Arms}

Existentialists do not believe in God because they consider if God exists, they have no freewill because their essence is predesignated. If God does not exist, they have freewill and are free to choose their own essence. When the priest comes to see Henry in the hospital, Henry admits that he does not love God and does not believe in God. He does believe in his relationship with Catherine Barkley. Thus, it can be said that Henry creates himself around the love that both Henry and Catherine share. According to him, there is no way of believing in God in the world that mercilessly kills Aymo, Rinaldi, the baby and "Now Catherine would die." Here, the existential theme of the sense of anxiety felt by Henry is evident. Same is the case with Catherine who tells the nurse that she does not have any religion and does not believe in God. She tells Henry: "You are my religion". This makes evident the existential theme of the loss of religious belief demonstrated by Hemingway in the novel.One of the explicit existential passages in the novel:

"I was always embarrassed by the words sacred, glorious, and sacrifice... We had heard them...had read them, on proclamations... and I had seen nothing sacred, and the things that were glorious had no glory.... Abstract words such as glory, honor, courage...were obscene beside the concrete names of villages, the numbers of roads, the names of rivers, the numbers of regiments and the dates". (Book-III, Chapter-27).

One of the major existentialist themes is that personal experience matters more than what is told you by religion and society. Self-made meaning is regarded as more philosophically valid than societal meanings and dogmas. In the novel, the words like "sacred", glorious, and "sacrifice" are explicitly religious words: glory is associated with the glory of Crusades, sacrifice is linked with the sacrifice of Jesus Christ etc. The words "honor" and "courage" were employed by politicians to justify the war, to motivate and manipulate people to participate in it. For Henry, these abstract words reflect the socio-political agendas of those who are responsible for the war, are not only meaningless but completely absurd to him according to his own bitter experience of the war.

I would have married him or anything. But then he wanted to go to war and I didn't know... I didn't know about anything then. I thought it would be worse for him. I though perhaps he couldn't stand it and then of course he was killed and that was the end of it." (Hemingway 19). As a result this she begins a relationship with Henry. However, this relationship is fake and contrived in the beginning. They superficially pretend they are in love, playing with the idea of it as a diversion from their painful reality. We sat on the flat stone bench and I held Catherine Barkley's hand. She would not let me put my arm around her. "Are you very tired?" She asked. "No." She looked down at the grass.

Henry is ready for the next phase of the book, where he chooses to add meaning to his life. The emptiness he feels is becoming unbearable and he seeks a purpose and reason to live. 
His relationship with Catherine has begun to take on more meaning. He begins to make different choices. This leads into the next Existential theme found in Hemingway's A Farewell to Arms, existence preceding essence. Henry is beginning to develop his essence, which obviously, according to Existentialists, can only begin after one exists in the world.

The characters in Hemingway's novels cannot accept the fact that life is absurd and futile, so they seek a reason to live. For Henry and Catherine, the war has caused this feeling of emptiness and absurdity. They develop a love for each other to fill the void they feel inside. Existentialists would say that they are forming their essence by making different choices.

\subsection{Hemingway's War Experiences Reflected lost hope}

Hemingway himself suffered a lot from the wars, both physically and psychologically. All the pains helped the formation of his viewpoints about the war-the senses of death and humanism. Surely he poured these senses into his fictions. From his works we see like Hemingway himself, the protagonists usually suffered both physical and psychological pains. They always lived in a violent world, wounded in the war and endured psychological ravages, such as insomnia, and frustration. The war has caused the men to lose hope and faith.

Beyond his physical wounds, Hemingway endured endless psychological pain resulted from the war and he surely transformed these into his arts. Hemingway suffered severe insomnia after the First World War. After the First World War, Hemingway also got a strong feeling of frustration. But no one, including his parents who still had a romantic notion of war, could understand the psychological impact the war had produced on him.

War is a major cause of such feelings of detachment in many works of literature. A Farewell to Arms is a story about Frederick Henry's process by which he removes himself from the war and leaves it behind. Even the priest that is with Henry in Italy has begun to feel alienation: "Now I am depressed myself," I said." That's why I never think about these things. I never think and yet when I begin to talk I say the things I have found out in my mind without thinking."'I had hoped for something."Defeat?"No. Something more. "There isn't anything more. Except victory. It may be worse."I hoped for a long time for victory. "ME too. "Now I don't know. "It has to be one or the other."I don't believe in victory anymore."I don't. But I don't believe in defeat. Though it may be better. "What do you believe in? "In sleep," I said. (Hemingway 179)

The war has caused the men to lose hope and faith. As discussed earlier, Henry turned to his love with Catherine throughout the war to get him through. When he leaves and lives with her to have their child, her painful labor threatens to take her life. Henry prays and begs for her to live: Poor, poor dear Cat. And this was the price you paid for sleeping together. This was the end of the trap. This is what people got for loving each other... So now they got her in the end. You never got away with anything. Get away hell! ... what if she should die? She won't die... She can't die. (320-321)

When Catherine and the child die, Henry does not know what do but see Catherine again. He enters her room but seeing her does not help; he is completely alienated. But after I had got them out and shut the door and turned off the light it wasn't any good. It was like saying good-by to a statue. After a while I went out and left the hospital and walked back to the hotel in the rain. (332) Henry has lost his love and his child, he has deserted the war, and the book ends with him alone in the rain, completely alienated. Existentialism takes a pessimistic view on life and man's existence, so the way in which A Farewell to Arms ends is very existentialist. 


\section{Conclusion}

To conclude, existential themes are plentiful in A Farewell to Arms. Full of anguish and grief, the characters of Ernest Hemingway's novel experience the absurdity of life, and try as they might to develop a positive essence by their choices, their lives end in sorrow and alienation. A Farewell to Arms shows that there is no solace to be found from a life in love and war. And there is nothing to be done. War is a major cause of such feelings of detachment in many works of literature. It makes hopeless in life. On the basis of these existential themes it is proved that the novel is an incarnation of existentialism. it is summed up that the novel includes some Existential notions and ideas explained in the novel based on these notions it can be summed up that the novel is the embodiment of the twentieth century philosophy, Existentialism.

\section{References}

Allen, J.G. (2005). Coping with Trauma: Hope through Understanding. Washington, D.C: American Psychiatric Publishing.

Barloon, Jim. (2005). "Very Short Stories: The Miniaturization of War in Hemingway's In Our Time." The Hemingway Review 24.2.

Basirizadeh, Fatewmeh sadat. Raoufzadeh, N. (2020). Transcendent Philosophy: A Comparative Study on Mulla Sadra and Kant. Budapest International Research and Critics Institute-Journal, 11-17. www.bircu-journal.com/index.php/birci

Eskandari, Safoura. (2020). Social and Religion Paralysis in James Joyce's Short Story The Sisters: A Cultural Reading. Budapest International Research and Critics InstituteJournal: 311-320. www.bircu-journal.com/index.php/birc

Hemingway, Ernest. (1969). A Farewell to Arms.

Nietzsche, Friedrich. (1995). Beyond Good and Evil: Prelude to a Philosophy of the Future. Great Books. Ed. Mortimer J. Adler. New York: Simon \& Schuster Inc.

Jean-Paul Sartre. (2003). Hemingway, Ernest. A Farewell to Arms. Truest- McConnell College. 2003.way, Ernest. A Farewell to Arms. New York: Scribner Classics. Print 